\title{
Punching resistance of internal slab-column connections with double-headed shear studs
}

\section{Resistência à punção de ligações laje-pilar interno com conectores de cisalhamento}
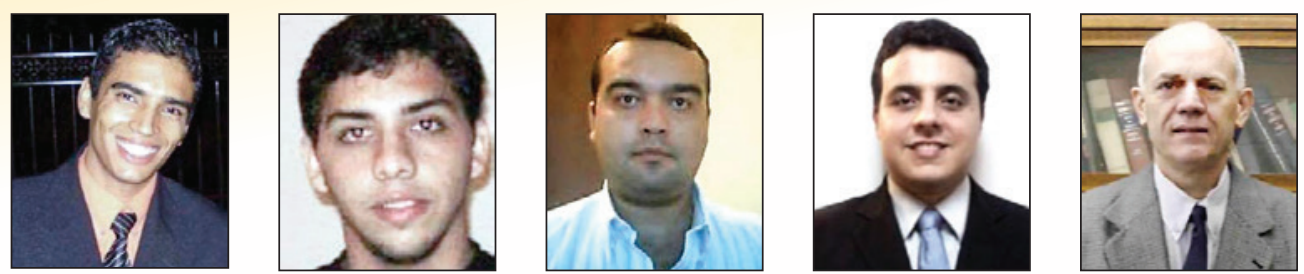

M. H. OLIVEIRA a honorato.eng@gmail.com.br

\section{J. M. PEREIRA FILHO ${ }^{\circ}$}

D. R. C. OLIVEIRA c mpina@ufpa.br

M. P. FERREIRA d denio@ufpa.br

G. S. S. A. MELO e melog@unb.br

\section{Abstract}

Punching shear is a brittle failure mode that may occur in slab-column connections, which may be prevented by using shear reinforcement in the slab-column connection. This paper presents comparisons between experimental results of 36 tests in internal slab-column connections with double- headed shear studs, which are largely used in North America, Europe and Asia, with theoretical results using recommendations presented by ACI 318, NBR6118, Eurocode 2 and also the Critical Shear Crack Theory (CSCT).Considering the database used it is possible to observe that ACI 318 presents conservative trends, whereas NBR 6118 showed a low coefficient of variation, but with a large number of unsafe results. Both Eurocode 2 and CSCT showed satisfactory results with Eurocode 2 presenting slightly higher performance.

Keywords: flat slabs, punching shear, double-headed studs.

\section{Resumo}

A punção é uma forma de ruptura por cisalhamento que pode ocorrer em ligações laje-pilar que pode ser evitada utilizando-se armaduras de cisalhamento na ligação. Este artigo apresenta comparações entre resultados experimentais de 36 ensaios realizados em ligações laje-pilar interno, armadas com conectores de cisalhamento do tipo pino de duas cabeças, populares na América do Norte, Europa e Asia, com resultados teóricos utilizando as recomendações do ACI 318, NBR 6118, Eurocode 2, além da Teoria da Fissura Crítica de Cisalhamento (TFCC). Para o banco de dados utilizado, o ACI 318 mostrou tendências conservadoras, enquanto que a NBR 6118 mostrou baixo coeficiente de variação, mas um grande número de resultados contra a segurança. Tanto o Eurocode 2, quanto a TFCC apresentaram resultados satisfatórios, com o Eurocode 2 apresentando desempenho ligeiramente superior.

Palavras-chave: lajes lisas, punção, conectores de cisalhamento.

\footnotetext{
a Professor, Departamento de Engenharia Civil, Universidade Federal de Goiás, honorato.eng@gmail.com.br, Catalão, Goiás, Brasil.

Engenheiro Civil, Mestrando em Estruturas, Faculdade de Engenharia Civil, Universidade Federal do Pará, Belém, Pará, Brasil.

Professor, Faculdade de Engenharia Civil, Universidade Federal do Pará, mpina@ufpa.br, Belém, Pará, Brasil.

Professor, Faculdade de Engenharia Civil, Universidade Federal do Pará, denio@ufpa.br, Belém, Pará, Brasil.

Professor, Departamento de Engenharia Civil e Ambiental, Universidade de Brasilia, melog@unb.br, Brasília, Distrito Federal, Brasil.
} 


\section{Introduction}

Flat slabs are laminated reinforced or prestressed concrete structures that are supported directly on columns. Its use is common in North American, European and Asian countries. In Brazil, this constructive system begins to stand out in the market of civil construction, mainly for its greater simplicity in the execution of the forms and rebars. Such situation can lead to reductions in labor costs and in construction time, besides attributing greater flexibility in the use of the built spaces.

Punching is a brittle failure mode by shear that may occur in structural elements such as slabs when submitted to concentrated loads or reactions, which may lead the structure to ruin through the progressive collapse. The punching shear resistance slab-column connection is one of the most important parameters in the design of flat slabs. During design, it is possible to reduce the intensity of the shear stresses in the slab-column connection through the located increase of the thickness of the slab by using drop panels or column capitals. Nevertheless, the best technical alternative to increase the punching resistance of slab-column connections is the use of shear reinforcement. Among the several kinds of shear reinforcements available, stand out the double-headed studs, which are very popular nowadays in constructions with flat slabs, mainly due to its efficient mechanical anchorage provided by the heads, which are forged to the rebars.

This paper aims to evaluate the recommendations presented by some of the main design codes for the estimation of punching resistance of reinforced concrete flat slabs with double-headed studs as shear reinforcement. This is performed through the comparison of the experimental results of 36 tests on flat slabs with the theoretical results obtained according to the recommendations presented by $\mathrm{ACl} 318 \mathrm{M}$ [1], Eurocode 2 [2] and NBR 6118 [3]. The experimental results are also compared to those obtained using the Critical Shear Crack Theory (CSCT) as presented by Ruiz and Muttoni [4]. These comparisons are relevant especially because the last version of $\mathrm{ACl}$ and the recent version of fib Model Code 2010 [5] (based on CSCT) present specific treatments for the cases of slabs with studs as shear reinforcement.

\section{Shear reinforcement}

In the design of a slab-column connections, if it is found that they do not meet safety limits regarding punching, its resistance may be enhanced adopting some actions, as the increase of the column section, of the slab thickness, of the flexural reinforcement ratio, of the compressive strength of concrete, or by using drop panels and column capitals. However, the increase of the column section or the use drop panels and capitals usually generate problems from the architectural point of view. The increase of the slab thickness may mean a substantial elevation of the structure and foundation costs. Finally, increasing either the flexural reinforcement ratio or the compressive strength of concrete would have poor efficiency. Thus, when it is desirable to increase the punching resistance, one of the most practicable solutions may be the use of shear reinforcement.

The efficiency of the shear reinforcement regarding the punching resistance of slab-column connections relies on several aspects, like the kind of reinforcement used, and the amount, arrangement, spacing and the number of perimeters used. It is also essential for their performance that appropriate anchoring conditions are guaranteed, being this, normally a critical point for most of the options of available reinforcements, once that slabs are slender elements. Other important aspect about the use of shear reinforcements in flat slabs refers to the practicality of its installation. The slab-column connection is submitted to high normal and shear stresses, being common the concentration of flexural bars in this area, what makes it difficult the distribution of shear reinforcements.

Several kinds of shear reinforcements were tested seeking to evaluate its efficiency. The first reinforcement tested in flat slabs were bent-up bars as the ones presented in Figure 1a. This kind of reinforcement was used in tests as the ones by Graf [6], Elstner and Hognestad [7] and Andersson [8]. They can be very efficient in increasing the punching resistance, provided that precautions are taken to avoid punching failures in the area immediately after the bent-up bars. For this purpose, it might be useful to combine other kinds of shear reinforcement with bent- up bars. Broms [9] associated bent-up bars in the first two perimeters with closed stirrups and was able to avoid punching failures.

Stirrups may also be used as shear reinforcement in flat slabs, having been tested closed stirrups (Figure 1b), one-legged open stirrups (Figure 1c), continuous u-shaped reinforcement like "shear combs" (Figure 1d), inclined stirrups (Figure 1e), among others. Closed and u- shaped stirrups are of difficult use because of building issues related to its assembly. One- legged stirrups showed poor anchorage in tests with flat slabs, even when adopting actions like bending its ends in $90^{\circ}$ or $180^{\circ}$ angles, or using horizontal bars passing inside these folds, as observed by Regan and Samadian [10]. Only inclined stirrups, as the ones used by Oliveira et al. [11] with a $60^{\circ}$ inclination, have shown to be efficient in increasing the punching resistance.

Studs (Figures $1 \mathrm{f}$ and $1 \mathrm{~g}$ ) have been largely used due to their good mechanical anchorage and once they are industrialized, it is easier to ensure a higher quality, and eliminate some activities of the construction site. Although studs are difficult to install, especially if the designer adopts a radial arrangement for them, they are the most popular shear reinforcement in the civil construction industry today. Figure $1 \mathrm{~h}$ presents shear heads, which are made with steel standard sections embedded in the connection. It is a type of reinforcement considered of a high cost, normally used when there is the necessity to let large holes in the area close to the connection and demand big adjusts in the flexural reinforcement around this area.

For cases of symmetric punching the distribution of the shear stresses around the slab-column connection is uniform. Thus, theoretically, the ideal would be to adopt a radial arrangement for the reinforcement, as indicated in Figure 2a. However, distributing the shear reinforcements in a radial shape usually generates big interferences with flexural reinforcements in the slab- columns connection. One alternative is to concentrate the shear reinforcement in orthogonal zones in a cruciform arrangement, as presented in Figure $2 \mathrm{~b}$. With the exception of $\mathrm{ACl}$, the other design codes use to penalize the punching resistance estimations for cases of connections with cruciform arrangements, considering in a general manner, that this would only be justified in cases of columns with high rectangularity index or for slab-column connections in panels with substantial asymmetry in terms of loading or geometry.

The shear reinforcement ratio and the number of perimeters of shear reinforcement surrounding the column or loaded area 
Figure 1 - Types of shear reinforcement for slab-column connections

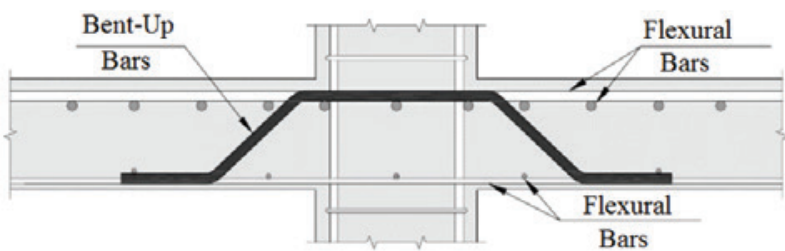

a) Bent-Up Bars

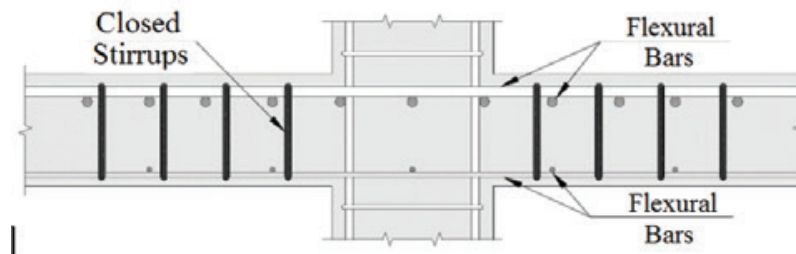

b) Closed Stirrups

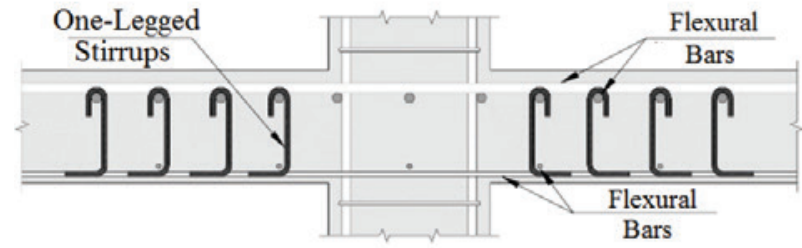

c) One-Legged Stirrups

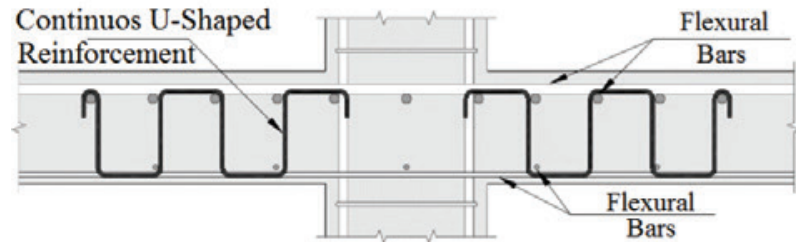

d) Continuos U-Shaped Reinforcement

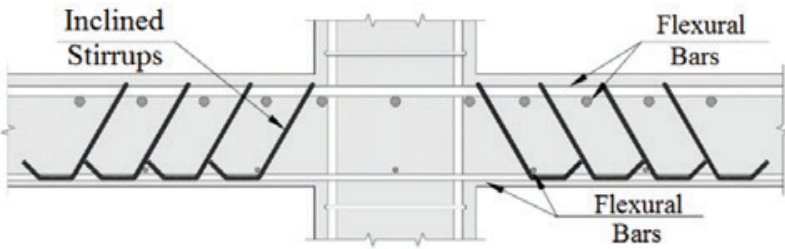

e) Inclined Stirrups

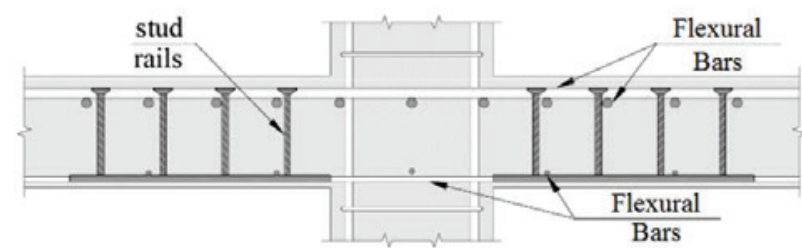

f) Single-headed studs on rails

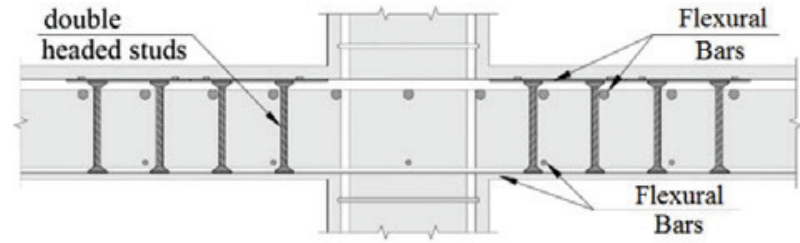

g) Double-headed studs

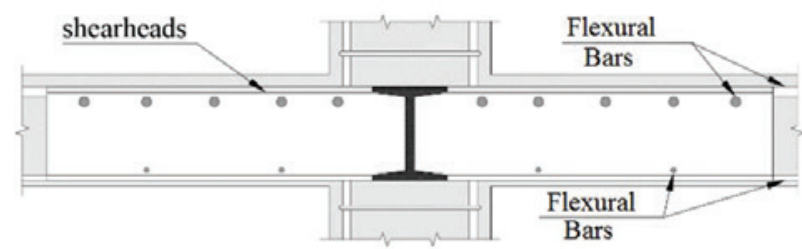

h) Shearheads 
Figure 2 - Different arrangements for shear reinforcements

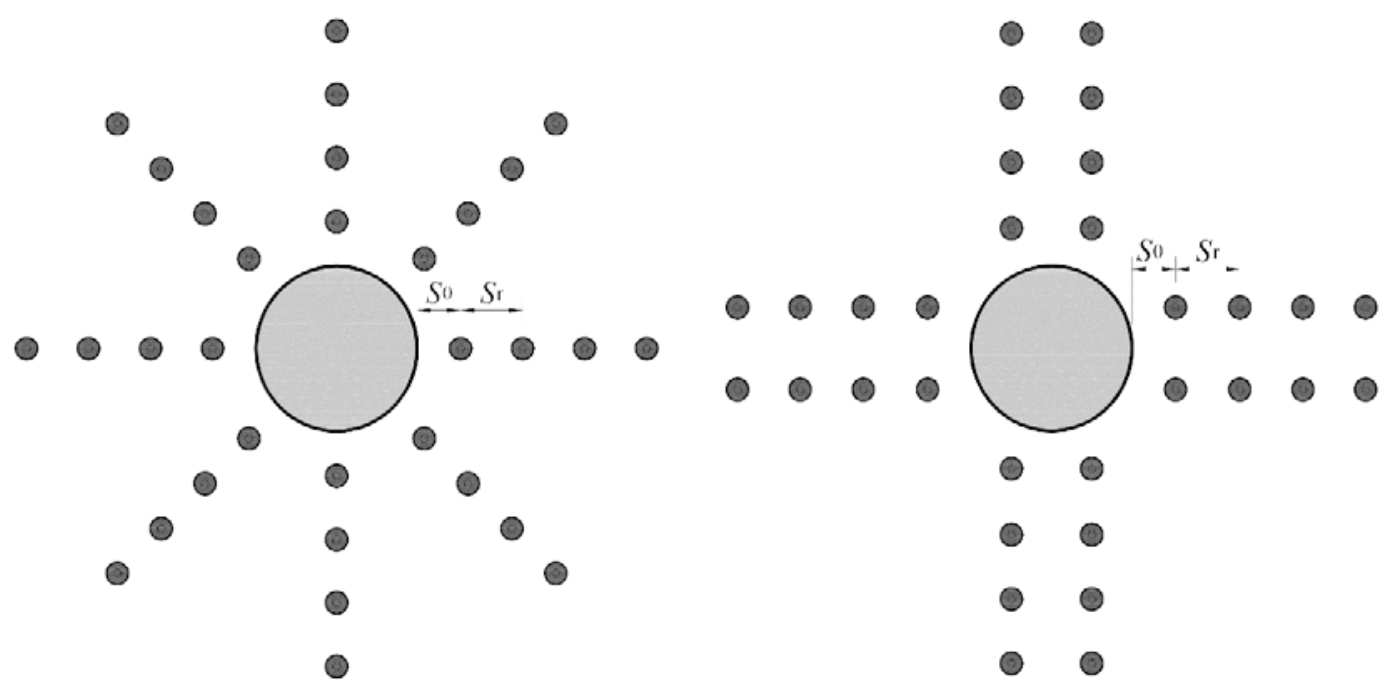

Radial

B Cruciform

Figure 3 - Punching shear failure modes for slabs with shear reinforcement

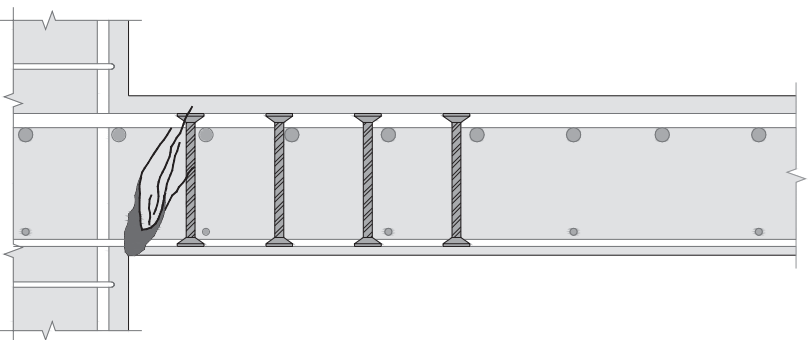

a) Crushing of concrete strut $\left(V_{\mathrm{R}, \max }\right)$

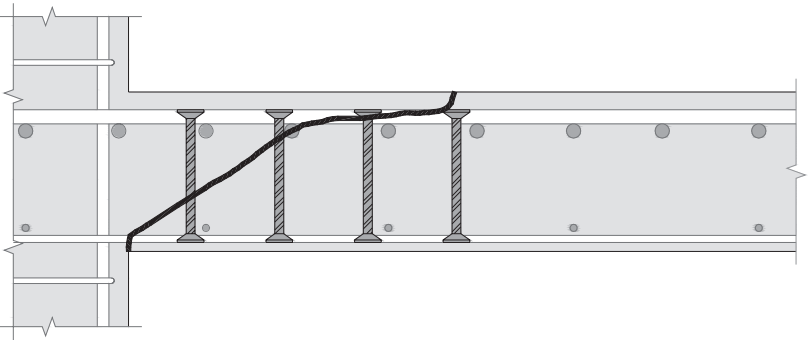

b) Diagonal tensile failure within the region with shear reinforcement $\left(V_{\mathrm{R}, \mathrm{cx}}\right)$

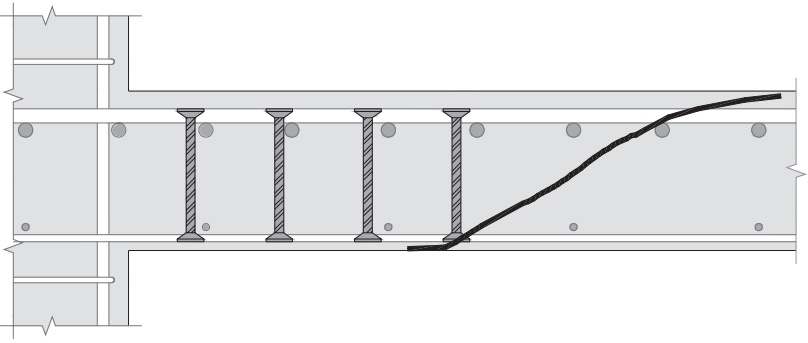

c) Diagonal tensile failure outside the region with shear reinforcement $\left(V_{\text {R,out }}\right)$ 
Figure 4 - Influence of the shear reinforcement in the load-displacement response - Dilger and Ghali (11)

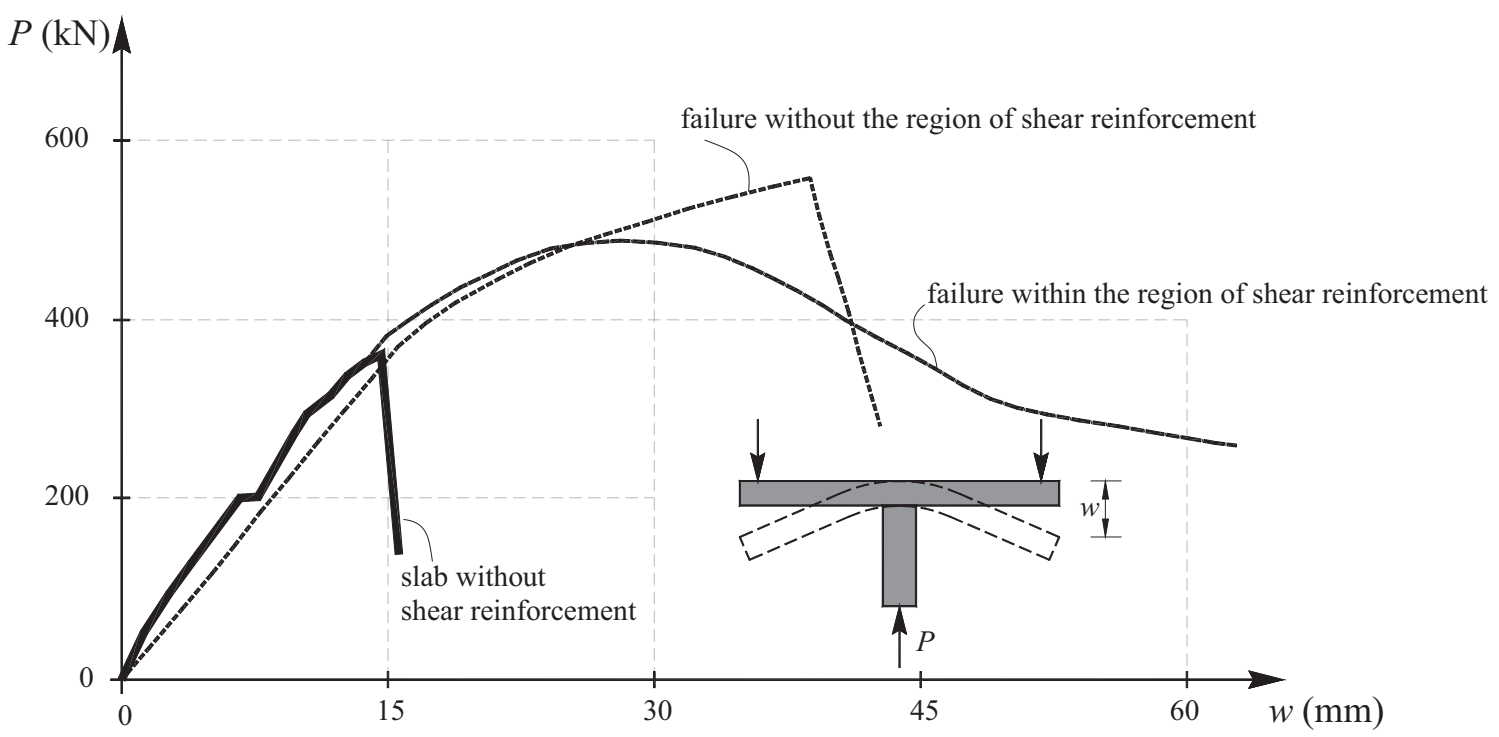

influence directly the punching shear failure mode, which may occur by crushing of a diagonal strut close to the column face or by diagonal tensile inside or outside the shear reinforced zone, as illustrated in Figure 3. Experimental evidences indicate that the position of punching failure cone substantially influences the ductility of the slab-column connection after the rupture. Figure 4, adapted from Dilger and Ghali [12], shows that when the rupture occurs out of the area reinforced to shear, the ruin can be as brusque as in the case of slabs without shear reinforcement.

Other important parameter in the definition of the punching resistance of slab-column connections is the distance of the first shear reinforcement perimeter in relation to the column face $\left(\mathrm{s}_{0}\right)$ and the spacing between subsequent perimeters $\left(s_{r}\right)$. In the case of the first layer $\left(\mathrm{s}_{0}\right)$, Eurocode 2 [2] recommends at least a distance of $0,3 d$. NBR 6118 [3] recommends that it is at most $0,5 d$, where $d$ is the effective depth of the slab. For the space between subsequent perimeters $\left(s_{r}\right)$, these codes suggest a maximum distance of $0,75 d$. Limitations for these values are important (see Figure 5). If the first perimeter of studs is placed too close to the column (very small $\mathrm{s}_{0}$ ) their lower anchorage may be poor. The same may happen with the posterior perimeters, but in their upper anchorages, if the space between layers is very high. In both cases, poor anchorage conditions may favor punching failures before the shear reinforcement yields.

\section{Theoretical methods for estimation of the punching resistence}

The codes considered in this paper and the Critical Shear Crack Theory admit that the punching resistance of flat slabs with shear reinforcement should be taken as the smaller value be-

\section{Figure 5 - Zones with critical anchorage conditions}

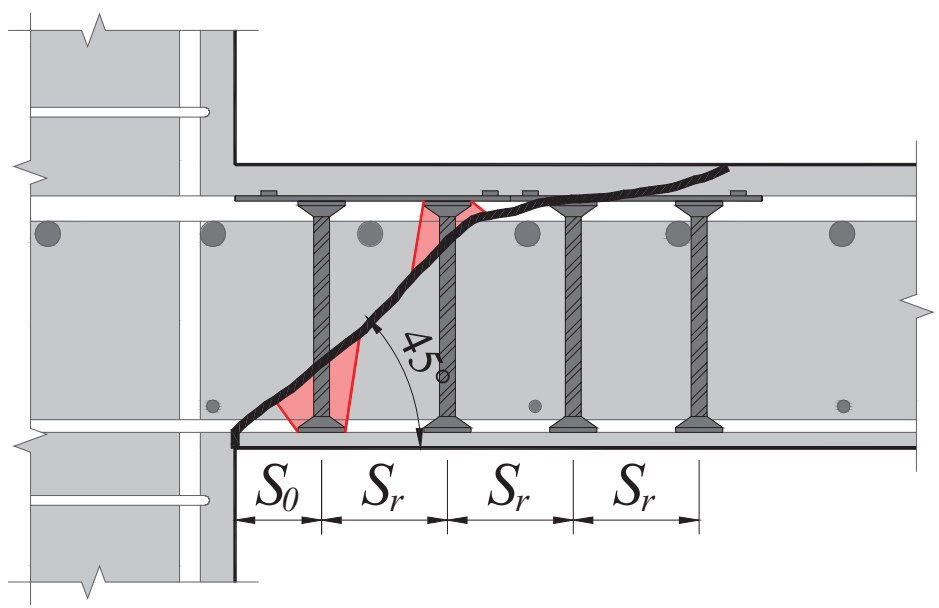


tween $V_{R, c s} V_{R \text {,out }}$ and $V_{R \text {,max }}$, corresponding to the failure modes indicated in Figure 3 , but not lower than $V_{R, c}$, which is the punching resistance of a slab with the same characteristics but without shear reinforcement. In the case of design codes, for the estimation of the punching resistance, the general principle adopted is to assume a constant resistant stress along different control perimeters. These control perimeters are admitted at specific distances from the column face, still having different geometries. The control perimeter $u_{0}$ is used to estimate the maximum punching resistance of a slab-column connection $\left(V_{R}\right.$,max $)$. The control perimeter $u_{1}$ is associated to the resistance to diagonal tension in the proximities of the column face, being used for the calculation of $V_{R, C}$ and $V_{R, c s}$. Finally, $u_{\text {out }}$ is a perimeter associated to the resistance to diagonal tension in the external area of the shear reinforcement, being associated to $V_{\mathrm{R} \text {,out }}$. The Critical Shear Crack Theory brings a methodology for the estimation of the punching resistance different from the one presented by the design codes.

\section{$3.1 \mathrm{ACl} 318 \mathrm{M}$}

The $\mathrm{ACl}$ expressions for the estimation of the punching resistance are presented in the Equations from 1 to 5 . Figure 6 presents some recommendation for the arrangement of the reinforcements and for the definition of the control perimeters. $\mathrm{ACl}$ presents specific expressions for the estimation of the punching resistance of flat slabs reinforced with studs. These equations are more optimistic in terms of considering the contribution of studs in the final punching resistance of slab-column connections $\left(V_{R, s}\right)$, if compared to the equations presented for all other kinds of shear reinforcement, showing that $\mathrm{ACl}$ assumes that studs present anchorage performance significantly higher than all other available shear reinforcements.

$$
V_{R, c}=\frac{1}{3} \cdot \sqrt{f_{c}} \cdot u_{1} \cdot d
$$

$$
V_{R, c s}=0,75 \cdot V_{R, c}+V_{R, s}
$$

$$
V_{\mathrm{R}, \mathrm{s}}=\frac{d}{s_{r}} \cdot A_{s w} \cdot f_{y w}, \text { with } f_{\mathrm{yw}} \leq 414 \mathrm{MPa}
$$

$$
V_{\mathrm{R}, \text { out }}=\frac{1}{6} \cdot \sqrt{f_{c}} \cdot u_{\text {out }} \cdot d
$$

$$
V_{\mathrm{R}, \max }=\frac{2}{3} \cdot \sqrt{f_{c}} \cdot u_{1} \cdot d, \text { if } s_{\mathrm{r}} \leq 0.5 d
$$

\section{Figure 6 - Rules for detailing and control perimeters - $\mathrm{ACI} 318 \mathrm{M}$}
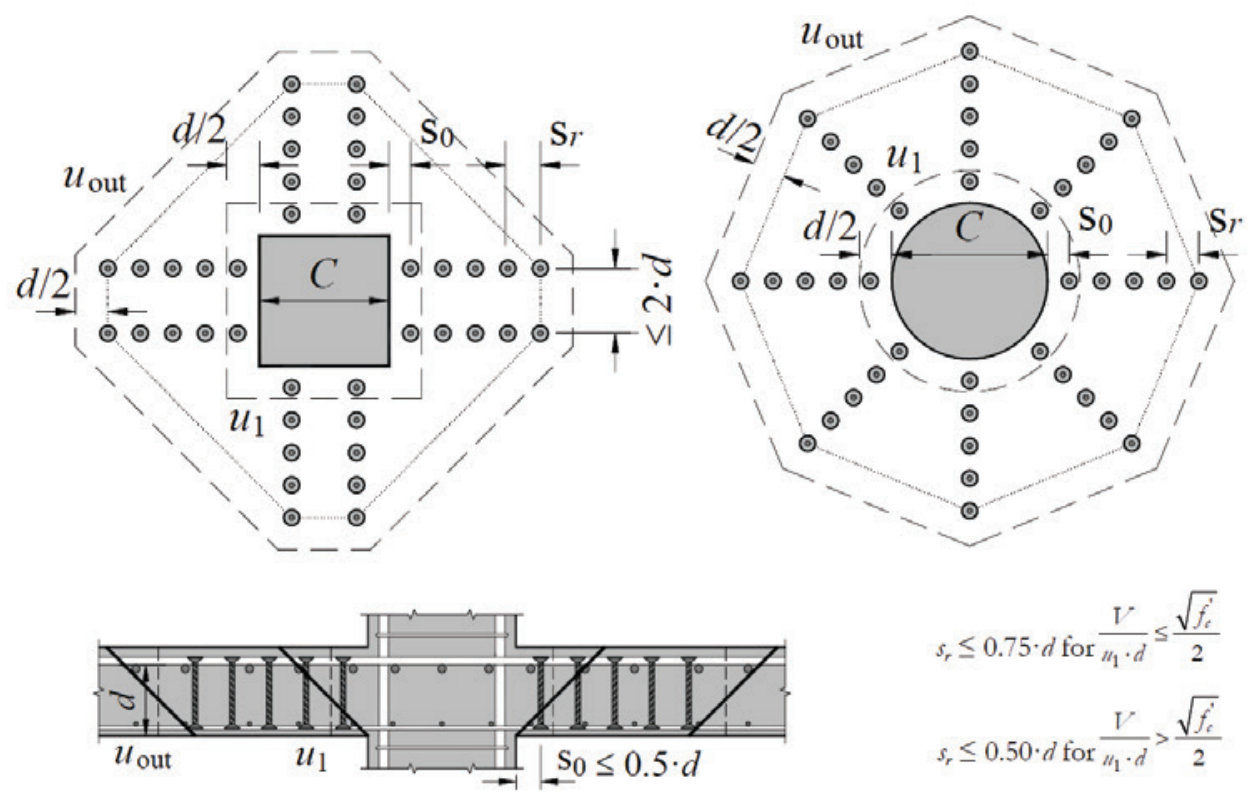

$$
\begin{aligned}
& s_{r} \leq 0.75 \cdot d \text { for } \frac{V}{\mu_{1} \cdot d} \leq \frac{\sqrt{f_{c}^{\prime}}}{2} \\
& s_{r} \leq 0.50 \cdot d \text { for } \frac{V}{\mu_{1} \cdot d}>\frac{\sqrt{f_{f}^{\prime}}}{2}
\end{aligned}
$$




\section{Figure 7 - Rules for detailing and control perimeters - NBR 6118}
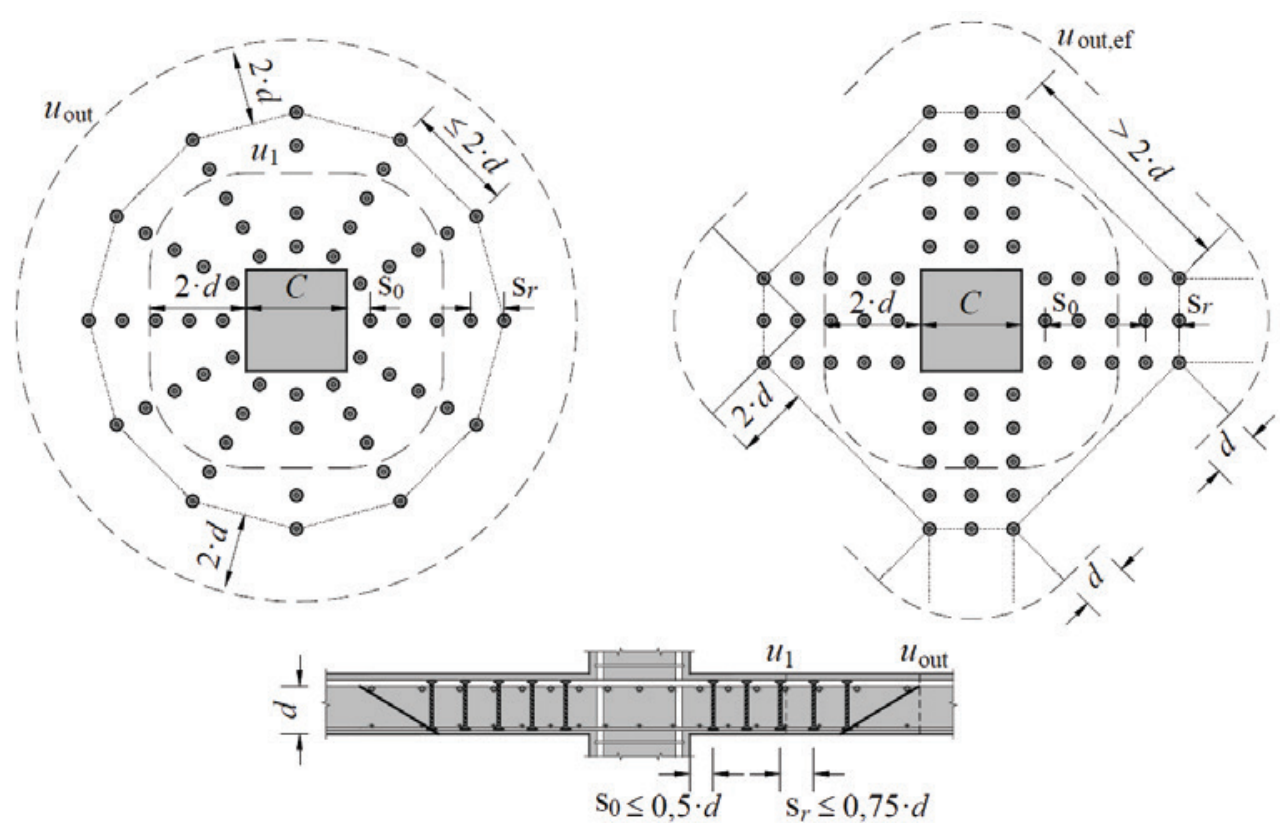

$$
V_{\mathrm{R}, \max }=\frac{1}{2} \cdot \sqrt{f_{c}} \cdot u_{1} \cdot d, \text { if } 0.5 d \leq s_{\mathrm{r}} \leq 0.75 d
$$

$$
V_{\mathrm{R}, c s}=0,75 \cdot V_{\mathrm{R}, c}+\left(1,5 \cdot \frac{d}{s_{r}} \cdot A_{s w} \cdot f_{y w, e f}\right)
$$

$f_{C}$ is limited to $\leq 69 \mathrm{MPa}$ for calculation purposes.

$A_{S W}$ is the area of steel of a layer of shear reinforcement;

$f_{y w}$ is the yield stress of the shear reinforcement, not higher than $420 \mathrm{MPa}$.

\subsection{NBR 6118}

The Brazilian code used as reference the design process adopted in CEB-FIPMC90 [13], presenting practically the same equations of this code, with small modifications, like the geometry of the external control perimeter for the case of slabs with reinforcements distributed in a radial form, which, in the case of the Brazilian code is circular. These recommendations are presented in a synthesized manner in the Equations 6 to 9 and in Figure 7. Notice that in this paper the equations are presented without the safety coefficient of 1.4 , which is implicit in the expressions presented by the Brazilian code.

$$
V_{\mathrm{R}, c}=0,18 \cdot \xi \cdot\left(100 \cdot \rho \cdot f_{c}\right)^{1 / 3} \cdot u_{1} \cdot d
$$

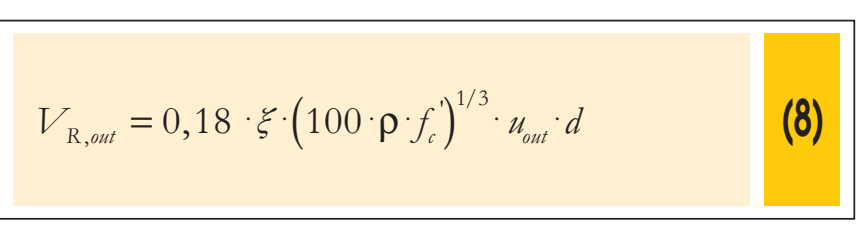

$$
V_{R, \text { máx }}=0,27 \cdot \alpha_{v} \cdot f_{c} \cdot u_{0} \cdot d
$$

\section{where}

$\mathrm{f}_{C}$ is limited to $50 \mathrm{MPa}$ for calculation purposes;

$\rho$ is the average tensioned flexural reinforcement ratio of the slab, calculated as $\rho=\sqrt{\rho_{x} \cdot \rho_{y}}$,

where $\rho_{\mathrm{x}}$ and $\rho_{\mathrm{y}}$ are the ratios in the directions $\mathrm{x}$ and $\mathrm{y}$, respectively;

Asw is the steel area of perimeters of shear reinforcement;

$\xi$ is the size effect, assumed as $\xi=1+\sqrt{\frac{200}{\mathrm{~d}}}$, with $\mathrm{d}$ in $\mathrm{mm}$;

$\alpha_{v}=\left(1-\frac{f_{c}}{250}\right)$ with fc in $\mathrm{MPa}$ 


\section{Figure 8 - Rules for detailing and control perimeters - Eurocode 2}

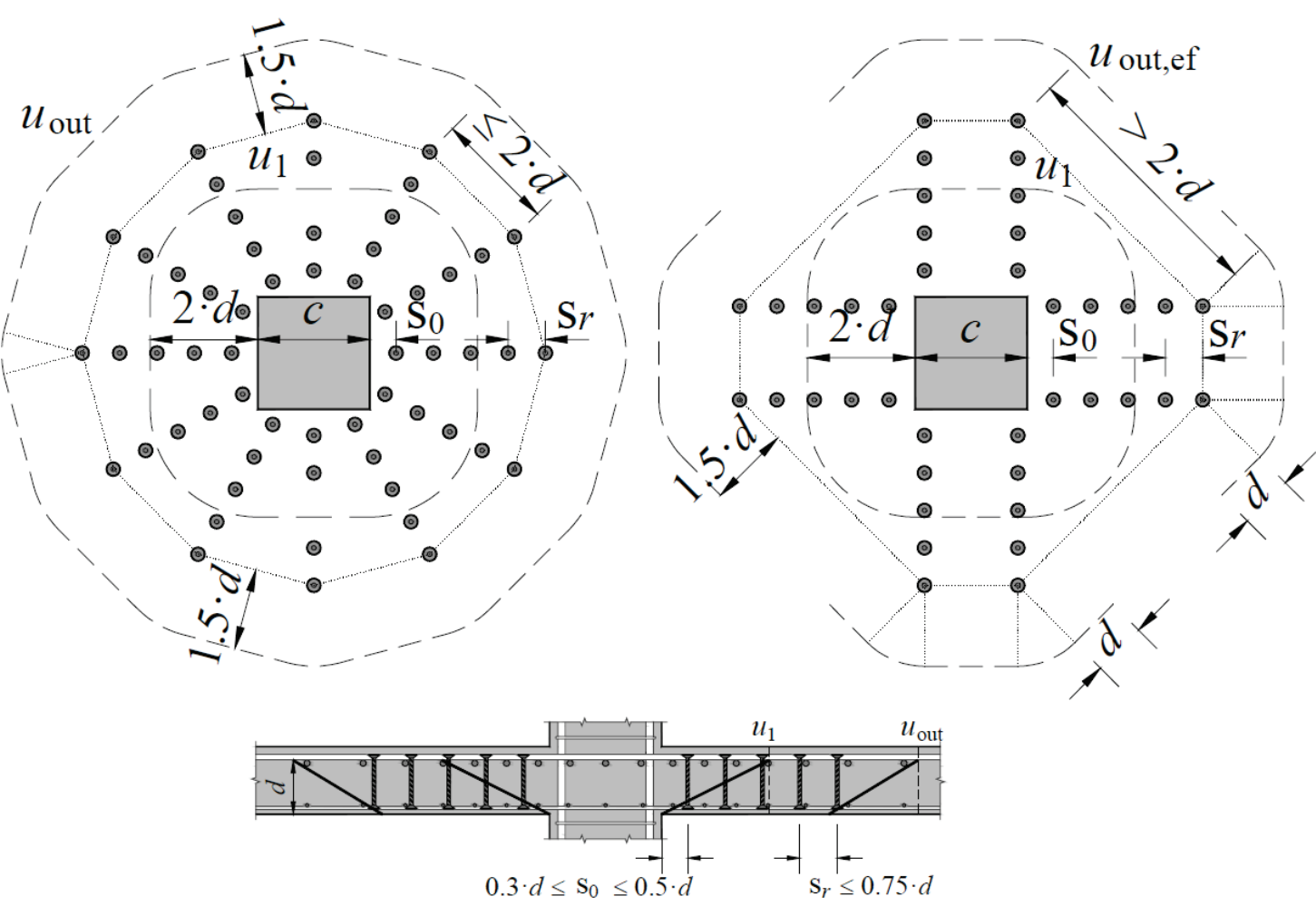

$f_{y w}$ is the yield stress of the shear reinforcement, not higher than $345 \mathrm{MPa}$ for studs or $288 \mathrm{MPa}$ for stirrups (steel CA-50 or CA-60).

\subsection{Eurocode 2}

Eurocode 2 [2] was also based on MC90. It presents recommendations similar to the ones available in the Brazilian code. The main differences between the prescriptions set by this code are the limitation of the size effect value in $k \leq 2,0$, the limitation of the flexural reinforcement ratio that effectively contributes in the punching resistance, considered as $\rho \leq 2 \%$ and the determination of the effective stress in the shear reinforcement. The equations 10 to 16 summarize the expressions presented by this code and Figure 8 helps in the determination of the control perimeters and in the reinforcement spacing.

$$
V_{R, c}=0,18 \cdot k \cdot\left(100 \cdot \rho \cdot f_{c}\right)^{1 / 3} \cdot u_{1} \cdot d
$$

$$
k=1+\sqrt{200 / d} \leq 2,0
$$

$V_{\mathrm{R}, c s}=0,75 \cdot V_{\mathrm{R}, c}+V_{\mathrm{R}, \mathrm{s}}$

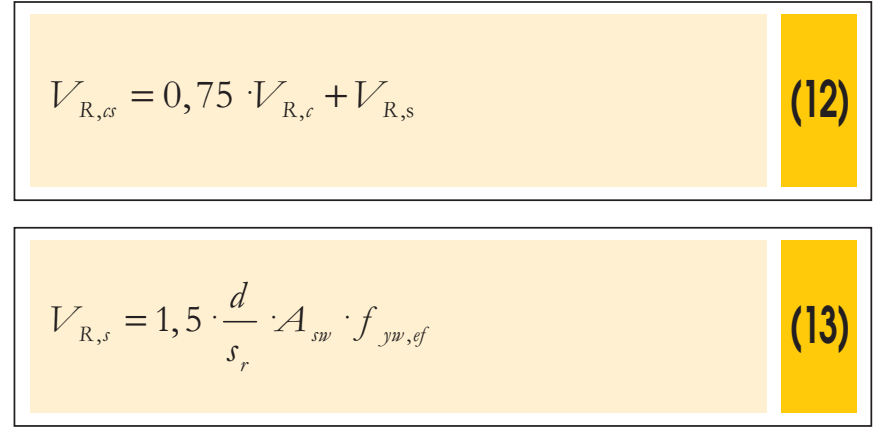

$f_{y w, e f}=1,15 \cdot(250+0,25 \cdot d) \leq f_{y w, e f} \leq 600 \mathrm{MPa}$

$$
V_{R, \text { out }}=0,18 \cdot k \cdot\left(100 \cdot \rho \cdot f_{c}^{\prime}\right)^{1 / 3} \cdot u_{\text {out }, e f} \cdot d
$$




$$
V_{\mathrm{R}, \text { máx }}=0,30 \cdot f_{c} \cdot\left(1-\frac{f_{c}}{250}\right) \cdot u_{0} \cdot d
$$

Where:

$\rho$ is the flexural reinforcement ratio calculated as $\rho=\sqrt{\rho_{x} \cdot \rho_{y}}$, where $\rho_{x}$ and $\rho_{y}$ are the reinforcements ratios in orthogonal directions determined for strips with width equals to the side of the column plus $3 \cdot d$ for both sides;

$\rho \leq 0,02$ for calculating purposes; $f_{\mathrm{C}} \leq 90 \mathrm{MPa}$.

\subsection{Critical shear crack theory (CSCT)}

This theory is based on the idea that the punching resistance decreases with the increase of the slab rotation, which can be explained by the arising of a critical shear crack that propagates through the slab cutting the compressed diagonal that transmits the shear force to the column (see Figure 9a). The opening of this crack reduces the resistance of the compressed strut and may eventually lead to a rupture by punching. According to Muttoni and Schwartz [14] the width of this crack is proportional to the product $\psi \cdot d$ (see Figure 9b). The shear transmission in the critical crack is directly connected to the roughness of its superficies which is a function of the maximum size of the coarse aggregate. Based on these concepts, Muttoni [15] proposes that the shear resistance piece given by the concrete may be estimated according to the Equation 17. Figure 10 presents the position and the geometry of the control perimeters according to CSCT.

$$
V_{R, c}=\frac{3}{4} \cdot \frac{u_{1} \cdot d \cdot \sqrt{f_{c}}}{1+15 \cdot \frac{\Psi \cdot d}{d_{g 0}+d_{g}}}
$$

Where:

$\psi$ is the slab rotation;

$d_{\mathrm{g} 0}$ is the reference diameter of the aggregate admitted as $16 \mathrm{~mm}$; $d_{\mathrm{g}}$ is the maximum aggregate diameter used in the slab concrete. The resistance piece provided by the vertical shear reinforcements cut by the rupture superficies can be obtained through Equation 18.

$$
V_{\mathrm{R}, s}=\sum A_{s w} \cdot f_{s w}
$$

Where:

$\Sigma$ is made for the shear reinforcements cut by the rupture superficies; $A_{S W}$ is the steel area of a layer of the shear reinforcement; $f_{S W}$ is the stress on each reinforcement layer, one in function of the details of the shear reinforcement and of the vertical displacements $\delta_{V}$ (see Equation 19) in each reinforcement layer at the point intercepted by the rupture superficies (see Table 1).

$$
\delta_{v}=\frac{\Psi \cdot s}{2 \cdot \sqrt{2}}
$$

\section{Figure 9 - Propagation of Critical Shear Crack - Adapted from Ruiz and Muttoni (4)}

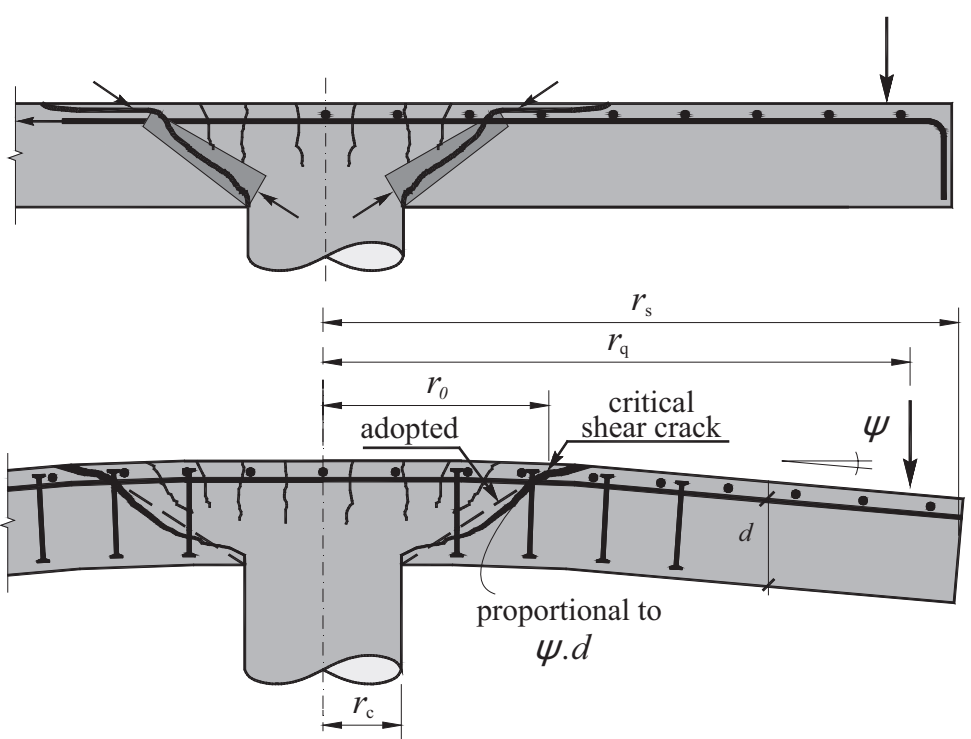

a)

b) 


\section{Figure 10 - Rules for detailing and control perimeters - CSCT}

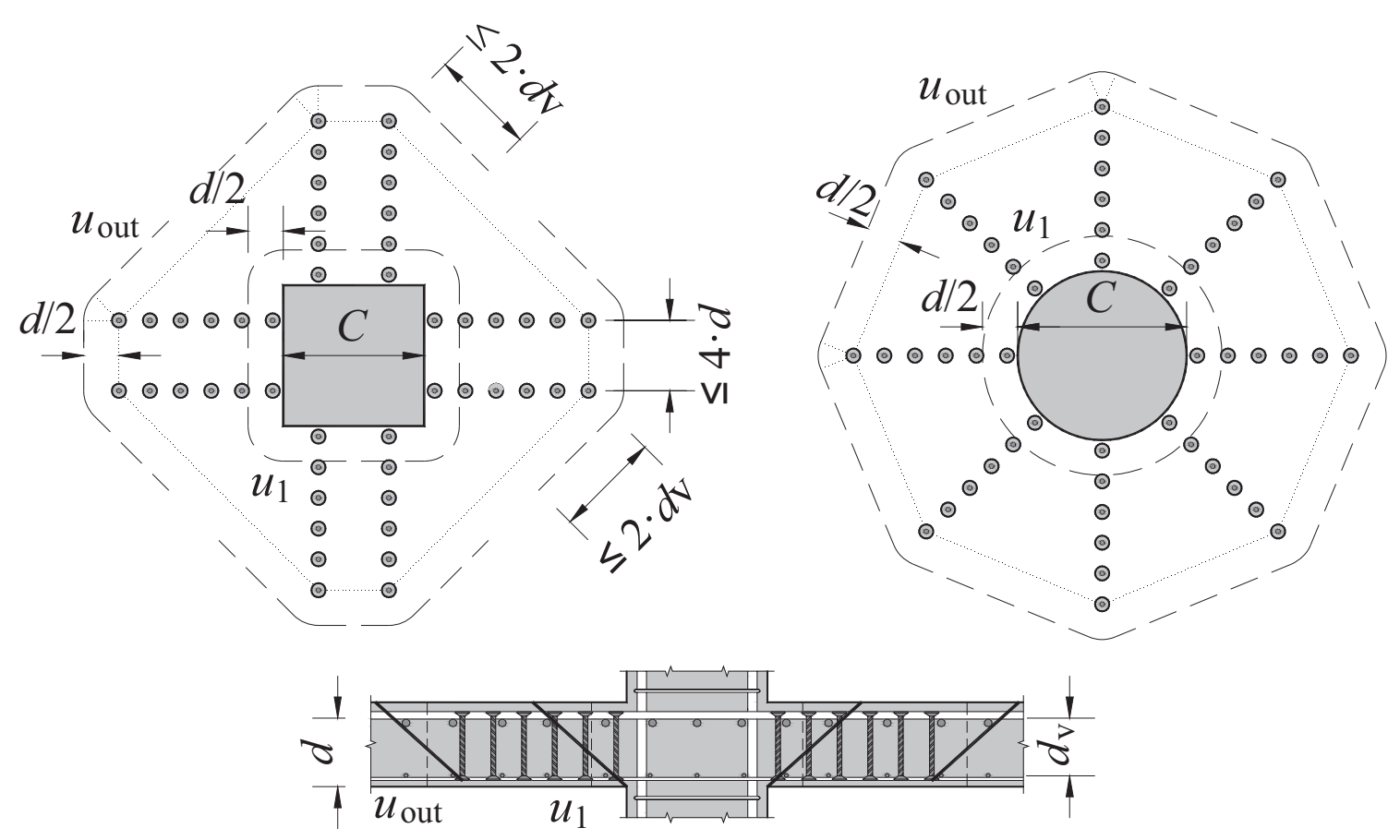

\section{Where:}

$s$ is the horizontal distance measured from the face of the column up to the layer of the shear reinforcements concerned.

The punching resistance of a flat slab of reinforced concrete with vertical shear reinforcement

can be obtained through Equation 20, being this function of $\psi$. The relation between the applied charge $\left(V_{\mathrm{E}}\right)$ and $\psi$ rotation is expressed by Equation 21.

$$
V_{\mathrm{R}, c s}=V_{\mathrm{R}, c}+V_{\mathrm{R}, s}
$$

$$
\Psi=1,5 \cdot \frac{r_{s}}{d} \cdot \frac{f_{y s, f}}{E_{s, f}} \cdot\left(\frac{V_{E}}{V_{f l e x}}\right)^{3 / 2}
$$

\section{Where:}

$r_{S}$ is the distance between the column axis and the null moment's line;

$f_{\mathrm{ys}, \mathrm{f}}$ is the yield stress of the flexural reinforcements;

$E_{\mathrm{S}, f}$ is the elasticity module of the flexural reinforcements;

$V_{E}$ is the applied force;

$V_{\text {flex }}$ is the resistance to flexion calculated through the theory of the rupture lines.

The resistance $V_{R \text {, max }}$ corresponding to the rupture by crushing of the compressed diagonal close to the column and can be calculated by Equation 22.

$$
V_{\mathrm{R}, \max }=\boldsymbol{\lambda} \cdot V_{\mathrm{R}, c}
$$

Where:

$\lambda$ is considered equals 3 for the cases of shear reinforcements well anchored like studs and 2 for the other types of shear reinforcements. In the case of ruptures occurring out of the region of the shear reinforcements we admit that the rupture superficies will also have inclination of $45^{\circ}$, but its extremity coincides with the inferior anchorage point of the most external shear reinforcement. In practice, this implies in the reduction of the effective death of the slab $(d)$ to an effective death $\left(d_{\mathrm{V}}\right)$, as can be seen in Figure 11. The control perimeter in this case is taken at a d/2 distance from the perimeter of the most external shear reinforcement layer. Equation 23 must be used for the calculation of $V_{\text {Rout. }}$

$$
V_{R, \text { out }}=\frac{3}{4} \cdot \frac{u_{\text {out }} \cdot d_{v} \cdot \sqrt{f_{c}^{\prime}}}{1+15 \cdot \frac{\psi \cdot d}{d_{g 0}+d_{g}}}
$$

Where:

$u_{\text {out }}$ is the external perimeter defined at a $d / 2$ distance from the 


\section{Table 1 - Relationship between $\mathrm{f}_{\mathrm{sw}}$ and $\delta_{\mathrm{v}}$ in studs with deformed bars}

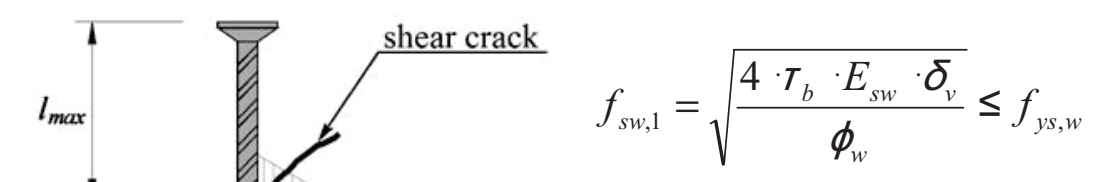

for

$\delta_{v} \leq \frac{4 \cdot T_{b}}{E_{s w} \cdot \phi_{w}} \cdot l_{\min }^{2}=\delta_{v, 1}$

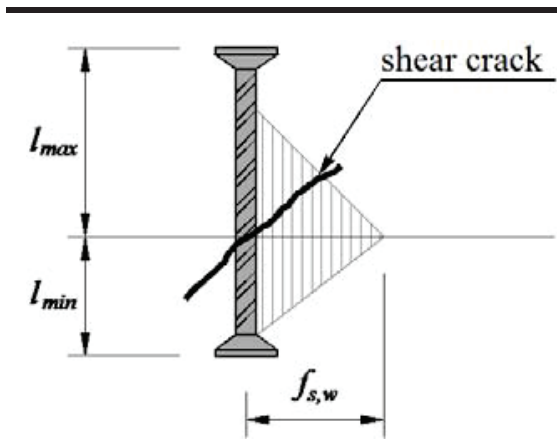

$f_{s w, 2}=\frac{\sqrt{2 \cdot l_{\min }^{2}+\frac{\phi_{w} \cdot E_{s w} \cdot \delta_{v}}{2 \cdot T_{b}}}-l_{\min }}{\frac{\phi_{w}}{4 \cdot T_{b}}} \leq f_{y s, w}$

for

$\delta_{v, 1} \leq \delta_{v} \leq \frac{2 \cdot T_{b}}{E_{s w} \cdot \phi_{w}} \cdot\left[\left(l_{\text {max }}+l_{\text {min }}\right)^{2}-2 \cdot l_{\text {min }}^{2}\right]=\delta_{v, 2}$

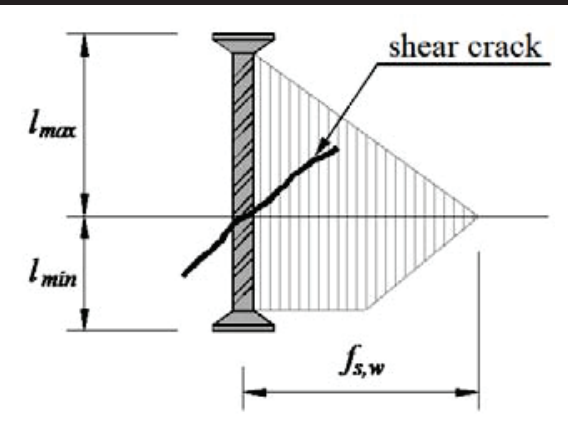

$f_{s w, 3}=\frac{E_{s w} \cdot \delta_{v}}{\left(l_{\max }+l_{\text {min }}\right)}+\frac{2 \cdot T_{b}}{\phi_{w}} \cdot\left(\frac{l_{\text {max }}^{2}+l_{\text {min }}^{2}}{l_{\text {max }}+l_{\text {min }}}\right) \leq f_{y s, w}$

for

$\delta_{v} \leq \delta_{v, 2}$

$T_{b}=5 \mathrm{MPa}$ to consider all previous equations

most external layer of the reinforcements, considering $4 \cdot d$ as the maximum effective distance between two concentric lines of shear reinforcements;

$d_{V}$ is the reduced effective death.
The Critical Shear Crack Theory is a graphic method for the determination of the punching resistance. The calculation process begins with the construction of a curve that relates the shear forces with the rotation of the slab-column connection, using the terms $V_{E}$

Figure 11 - Failure in the region outside the shear reinforcement - Ruiz and Muttoni (4) 
Figure 12 - Example of the estimation of punching shear strength according to the CSCT

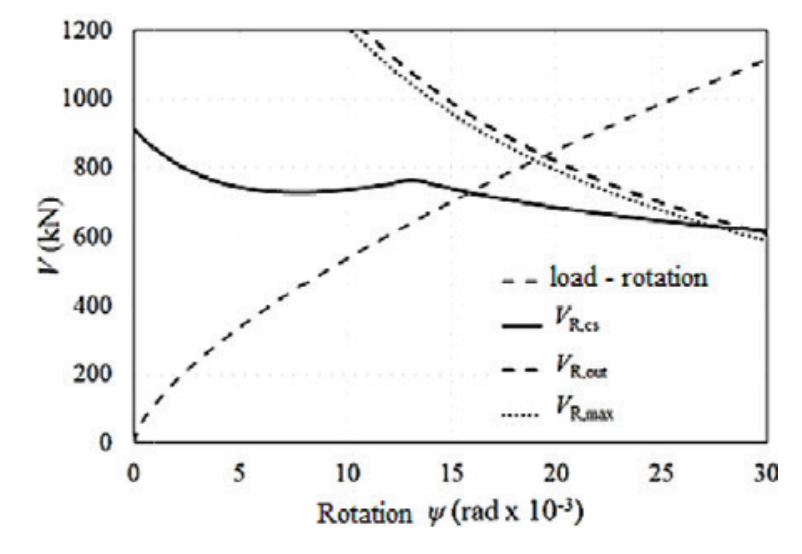

and $\psi$. Subsequently, this graphic is added to the rupture criteria set by the equations presented above, generating curves $V_{\mathrm{R}, \mathrm{cs}}$ $-\psi, V_{\mathrm{R}, \operatorname{Max}}-\psi$ e $V_{\mathrm{R}, \text { out }}-\psi$. The intersection point of these resistance curves with the load-rotation curve defines the connection resistance for each one of the rupture modes. Figure 12 illustrates the graphic process used for the estimation of the resistance to punching according to CSCT.

\section{Analysis of theoretical methods}

The results presented and evaluated in this paper are originated from the creation of a data basis that counts on results obtained by several authors who studied the case of the flat slabs with shear reinforcement and submit to symmetric loading. It was sought in the formation of this data basis to select only results of reinforced slabs with double-headed studs or with other types of reinforcement which present similar mechanical behavior, once these reinforcements are intentionally considered the most efficient in the resistance to punching due to its best mechanical anchorage.

Thus, the data basis counts only on the results of 36 experimental tests. It was opted not to use results of slabs with other kinds of shear reinforcement, to evaluate the accuracy and appropriation of the hypothesis admit by the theoretical methods previously presented to estimate the punching resistance in cases of slabs with shear reinforcement considered of a good anchorage. Slabs tested by Regan [16], Birkle [17], Regan and Samadian [10], Gomes and Regan [18] and Cordovil [19] were selected.

Regan [16] slabs were not published in scientific media of public access, so these results were passed through personal correspondence with the author, having its proper authorial concession. From the slabs tested by Birkle [17], nine slabs had shear reinforcement and three slabs were used as reference. This author's slabs are important due to the elevated thickness they had, providing valuable results in relation to the size effect. All of the selected slabs tested by Regan and Samadian [10] presented shear reinforcements type double-headed stud, being their results important for the evaluation of the prescriptions for rupture modes occurring out of the area with shear reinforcement. From the 11 slabs
Table 2 - Criteria for evaluating $\mathrm{V}_{\mathrm{u}} / \mathrm{V}_{\text {too }}$

\begin{tabular}{|cc|}
\hline $\begin{array}{c}\text { Criteria for } \\
\text { evaluating }\end{array}$ & Classification \\
$\mathrm{V}_{\mathrm{u}} / \mathrm{V}_{\text {teo }}<0,95$ & Unsafe \\
$0,95 \leq \mathrm{V}_{\mathrm{u}} / \mathrm{V}_{\text {teo }} \leq 1,15$ & Precise \\
$1,15<\mathrm{V}_{\mathrm{u}} / \mathrm{V}_{\text {teo }} \leq 1,30$ & Satisfactory \\
$\mathrm{V}_{\mathrm{u}} / \mathrm{V}_{\text {teo }}>1,30$ & Conservative \\
\hline
\end{tabular}

tested by Gomes and Regan [18], one of them did not have shear reinforcement and ten had reinforcements formed by slices of I sections, having these reinforcements mechanical behavior similar to double-headed studs. Finally, from the slabs tested by Cordovil [19], three slabs had shear reinforcement and one slab was used as reference. These slabs provided results for small thicknesses and for the use of shear reinforcement ratio relatively low.

The analyses performed in this article consisted basically of comparing the rupture load obtained in the tests with the theoretical loads estimated by the methods presented. To evaluate the accuracy and the safety of these theoretical methods, these authors set the criterion presented on Table 2, which has as a basis the relation $V_{u} / V_{\text {teo }}$ (being $V_{u}$ the last test charge and $V_{\text {teo }}$ the last load estimated by the theoretical method under evaluation). Figure 13 presents general characteristics of the slabs used in the data basis and Table 3 shows all the variables of the tested models, used as entry values in the calculations performed. Table 4 presents the results of the tests and the theoretical estimations, besides a simplified statistic evaluation, considering the results average and its respective coefficient of variations.

Analyzing the results of the North American code ACI 318M [1], it becomes evident that among all estimations of ultimate load, this one presented the most conservative predictions, having for the relation $V_{u} / V_{\mathrm{ACl}}$ a 1.48 average value and a 0.19 coefficient of variation. This fact is associated to the fact that this code underestimates the contribution of the steel for the punching resistance. Comparing these expressions to consider the contribution of the AClconcrete to the ones of Eurocode and with the ones of NBR 6118 , we have $V_{\mathrm{R}, \mathrm{CACl}} / V_{\mathrm{R}, \mathrm{CEC} 2}$ has a 0.85 average value and for NBR the relation $V_{R, C A C l} / V_{R, c N B R}$ has a 0.79 average value. It proves the conservatism of ACl in relation to the piece of contribution of the concrete in the punching resistance. This same conservatism is seen when compared to the relation of the steel resistance parcel $V_{\mathrm{R}, \mathrm{sACl}} / V_{\mathrm{R}, \mathrm{sEC}}$ with a 0,86 average value and the relation $V_{\mathrm{R}, \mathrm{sACl}} / V_{\mathrm{R}, \mathrm{sNBR}}$ with a 0.76 average value.

This code also presents a strong tendency to predict ruptures in a critical perimeter out of the area of the shear reinforcement, presenting this kind of rupture in $89 \%$ of its predicts, besides presenting in a general way a mistake of $45 \%$ in all predictions of the rupture superficies. Although $\mathrm{ACl}$ considers at a more appropriate form for the anchorage condition of the different types of shear reinforcement, its conservatism in relation to the resistant capacity of the materials perhaps must be reevaluated. This fact leads to the discussion that the North American code might have its prescriptions adjusted for the case analyzed here, aiming at avoiding 


\section{Figure 13 - Details of the slabs of the database}

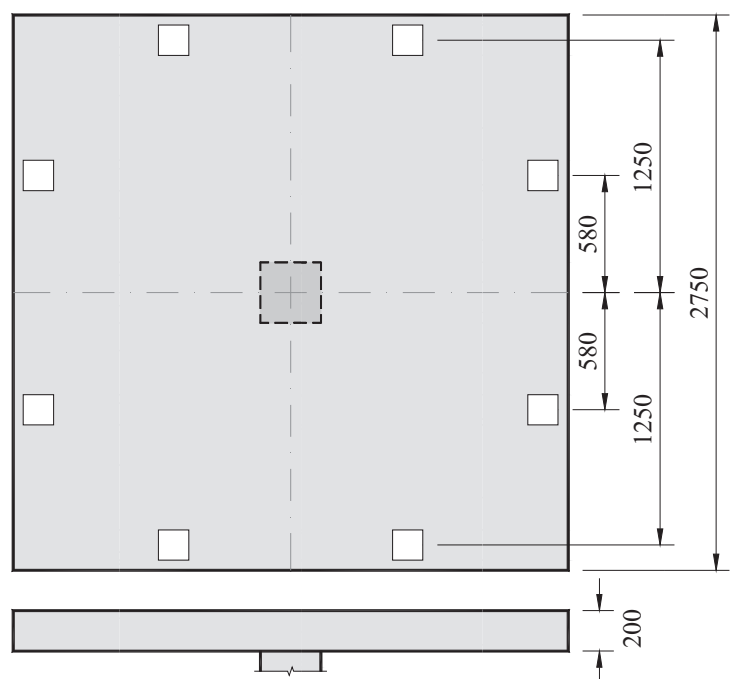

A Regan (16)
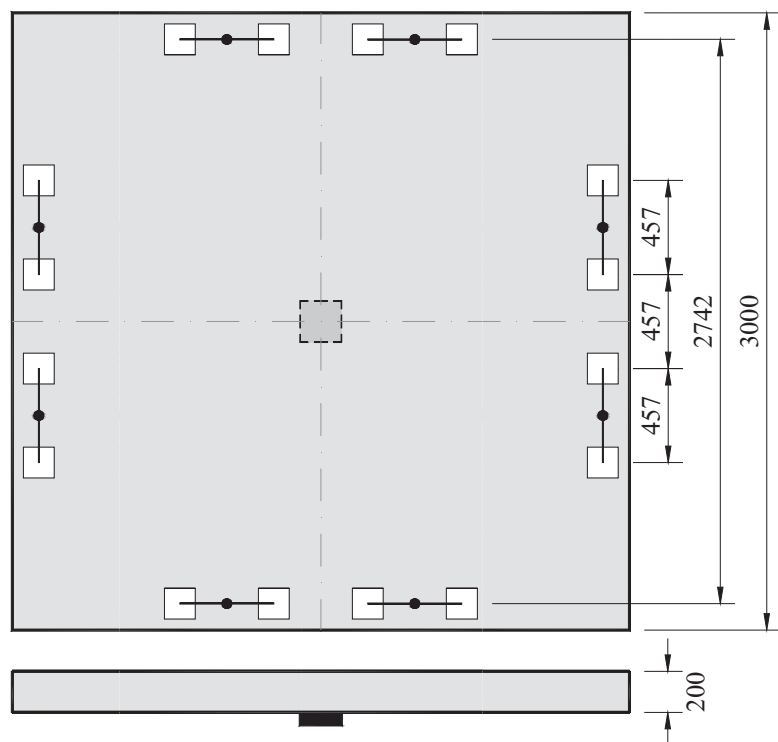

C Gomes e Regan (18); Regan and Samadian (10)

$\longrightarrow$ : cylinder or tie causing two loads or reactions;

- $\quad$ : cylinder or tie; (cylinders below the columns not shown)

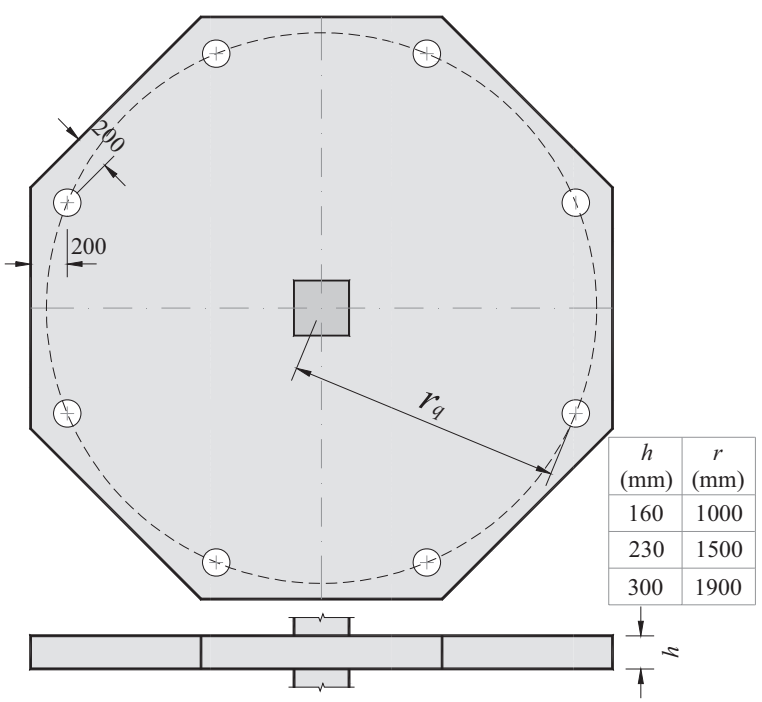

B Birkle (17)

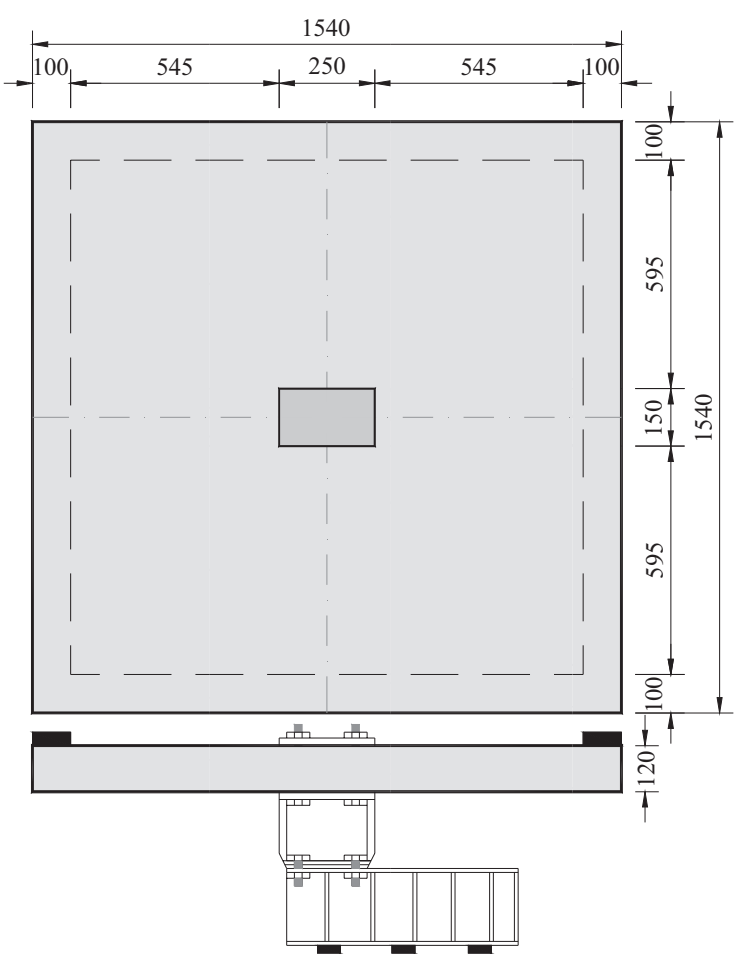

D Cordovil (19) 
safety levels considered exaggerated and which may lead to an anti-economics dimensioning.

Evaluating NBR 6118 [3] and having as a basis the classification of the normative performance level presented in Table 4, it is possible to say that this code presents very accurate average results. Although it has presented relation $V_{\mathrm{u}} / V_{\mathrm{NBR}}$ with a 0.97 general average and a 0.11 coefficient of variation, the safety level of the equations of NBR 6118 is questionable, once that for $64 \%$ of the slabs its results were against safety, with the code estimating a resistant capacity superior to the one observed in the tests. In relation to the prediction of the rupture superficies, this code presented results considered satisfactory, hitting $71 \%$ of its Predictions.

Among the analyzed codes, Eurocode 2 [2] was the one that presented the best results, presenting for the relation $V_{\mathrm{U}} / V_{\mathrm{EC} 2}$ a 1.13 average value, a 0.12 coefficient of variation and only $11 \%$ of results against safety. However, the results presented in Table 3 show that EC2 presents a strong tendency to predict rupture out of the area with shear reinforcement, having predicted this kind of

\section{Table 3 - Slabs characteristics}

\begin{tabular}{|c|c|c|c|c|c|c|c|c|c|c|c|c|c|c|c|c|}
\hline Author & Slab & $\underset{(\mathrm{mm})}{\mathrm{d}}$ & $\begin{array}{c}\mathrm{C} \\
(\mathrm{mm})\end{array}$ & $\begin{array}{c}p \\
(\%)\end{array}$ & $\underset{(\mathrm{mm})}{\emptyset_{\mathrm{w}}}$ & Lines & $\begin{array}{c}\mathrm{A}_{\mathrm{sw}} / \\
\text { Layer } \\
\left(\mathrm{mm}^{2}\right)\end{array}$ & Perimeters & $\begin{array}{c}S_{0} \\
(\mathrm{~mm})\end{array}$ & $\begin{array}{c}\mathrm{S}_{\mathrm{t}} \\
(\mathrm{mm})\end{array}$ & $\begin{array}{c}f_{c} \\
(\mathrm{MPa})\end{array}$ & $\begin{array}{c}f_{y_{s}} \\
(M P a)\end{array}$ & $\begin{array}{c}E_{s, 1} \\
(G P a)\end{array}$ & $\begin{array}{c}f_{y s, w} \\
(M P a)\end{array}$ & $\begin{array}{c}E_{s, w} \\
(\mathrm{GPa})\end{array}$ & $\begin{array}{c}d_{g} \\
(m m)\end{array}$ \\
\hline \multirow{3}{*}{$\begin{array}{l}\text { Regan } \\
(2009)\end{array}$} & 1 & 150 & 300 & 1,45 & 10 & 10 & 785 & 4 & 80 & 120 & 33 & 550 & 210 & 550 & 210 & 20,0 \\
\hline & 2 & 150 & 300 & 1,76 & 10 & 12 & 942 & 6 & 60 & 100 & 30 & 550 & 210 & 550 & 210 & 20,0 \\
\hline & 3 & 150 & 300 & 1,76 & 12 & 10 & 1.131 & 5 & 60 & 120 & 26 & 550 & 210 & 550 & 210 & 20,0 \\
\hline \multirow{12}{*}{$\begin{array}{l}\text { Birkle } \\
(2004)\end{array}$} & S1 & 124 & 250 & 1,53 & - & - & - & - & - & - & 36 & 488 & 195 & - & - & 14,0 \\
\hline & S2 & 124 & 250 & 1,53 & 10 & 8 & 567 & 6 & 45 & 90 & 29 & 488 & 195 & 393 & 200 & 14,0 \\
\hline & S3 & 124 & 250 & 1,53 & 10 & 8 & 567 & 6 & 45 & 90 & 32 & 488 & 195 & 393 & 200 & 14,0 \\
\hline & S4 & 124 & 250 & 1,53 & 10 & 8 & 567 & 5 & 30 & 60 & 38 & 488 & 195 & 465 & 200 & 14,0 \\
\hline & S5 & 124 & 250 & 1,53 & 10 & 8 & 567 & 7 & 30 & 60 & 36 & 488 & 195 & 465 & 200 & 14,0 \\
\hline & S6 & 124 & 250 & 1,53 & 10 & 8 & 567 & 7 & 30 & 60 & 33 & 488 & 195 & 465 & 200 & 14,0 \\
\hline & S7 & 190 & 300 & 1,29 & - & - & - & - & - & - & 35 & 531 & 200 & - & - & 20,0 \\
\hline & S8 & 190 & 300 & 1,29 & 10 & 8 & 567 & 5 & 50 & 100 & 35 & 531 & 200 & 460 & 200 & 20,0 \\
\hline & S9 & 190 & 300 & 1,29 & 10 & 8 & 567 & 6 & 75 & 150 & 35 & 531 & 200 & 460 & 200 & 20,0 \\
\hline & $S 10$ & 260 & 350 & 1,10 & - & - & - & - & - & - & 31 & 524 & 200 & - & - & 20,0 \\
\hline & S11 & 260 & 350 & 1,10 & 13 & 8 & 1.013 & 5 & 65 & 130 & 30 & 524 & 200 & 409 & 200 & 20,0 \\
\hline & $\mathrm{S} 12$ & 260 & 350 & 1,10 & 13 & 8 & 1.013 & 6 & 95 & 195 & 34 & 524 & 200 & 409 & 200 & 20,0 \\
\hline \multirow{6}{*}{$\begin{array}{l}\text { Regan } \\
\text { and } \\
\text { Samadian } \\
(2001)\end{array}$} & R3 & 160 & 200 & 1,26 & 12 & 8 & 905 & 4 & 80 & 120 & 33 & 670 & 210 & 442 & 210 & 20,0 \\
\hline & R4 & 160 & 200 & 1,26 & 12 & 8 & 905 & 6 & 80 & 80 & 39 & 670 & 210 & 442 & 210 & 20,0 \\
\hline & $\mathrm{Al}$ & 160 & 200 & 1,64 & 10 & 8 & 628 & 6 & 80 & 80 & 37 & 570 & 210 & 519 & 210 & 20,0 \\
\hline & $\mathrm{A} 2$ & 160 & 200 & 1,64 & 10 & 8 & 628 & 4 & 80 & 120 & 43 & 570 & 210 & 519 & 210 & 20,0 \\
\hline & R5 & 240 & 500 & 0,72 & 14 & 12 & 1.847 & 4 & 90 & 60 & 32 & 550 & 210 & 350 & 210 & 20,0 \\
\hline & R6 & 236 & 350 & 0,67 & 14 & 8 & 1.232 & 5 & 70 & 140 & 25 & 550 & 210 & 350 & 210 & 20,0 \\
\hline \multirow{11}{*}{$\begin{array}{l}\text { Gomes } \\
\text { and } \\
\text { Regan } \\
\text { (1999) }\end{array}$} & 1 & 159 & 200 & 1,27 & - & - & - & - & - & - & 40 & 680 & 215 & - & - & 20,0 \\
\hline & 2 & 153 & 200 & 1,32 & 6 & 8 & 226 & 2 & 80 & 80 & 34 & 680 & 215 & 430 & 205 & 20,0 \\
\hline & 3 & 158 & 200 & 1,27 & 7 & 8 & 301 & 2 & 80 & 80 & 39 & 670 & 185 & 430 & 205 & 20,0 \\
\hline & 4 & 159 & 200 & 1,27 & 8 & 8 & 402 & 3 & 80 & 80 & 32 & 670 & 185 & 430 & 205 & 20,0 \\
\hline & 5 & 159 & 200 & 1,27 & 10 & 8 & 628 & 4 & 80 & 80 & 35 & 670 & 185 & 430 & 205 & 20,0 \\
\hline & 6 & 159 & 200 & 1,27 & 10 & 8 & 628 & 4 & 80 & 80 & 37 & 670 & 185 & 430 & 205 & 20,0 \\
\hline & 7 & 159 & 200 & 1,27 & 12 & 8 & 905 & 5 & 80 & 80 & 34 & 670 & 185 & 430 & 205 & 20,0 \\
\hline & 8 & 159 & 200 & 1,27 & 12 & 8 & 905 & 6 & 80 & 80 & 34 & 670 & 185 & 430 & 205 & 20,0 \\
\hline & 9 & 159 & 200 & 1,27 & 12 & 8 & 940 & 9 & 80 & 80 & 40 & 670 & 185 & 430 & 205 & 20,0 \\
\hline & 10 & 154 & 200 & 1,31 & 6 & 8 & 226 & 5 & 80 & 80 & 35 & 670 & 185 & 430 & 205 & 20,0 \\
\hline & 11 & 154 & 200 & 1,31 & 7 & 8 & 301 & 5 & 80 & 80 & 35 & 670 & 185 & 430 & 205 & 20,0 \\
\hline \multirow{4}{*}{$\begin{array}{l}\text { Cordovil } \\
\text { (1995) }\end{array}$} & 7 & 131 & 100 & 0,85 & - & - & - & - & - & - & 34 & 500 & 199 & - & - & 19,0 \\
\hline & 8 & 131 & 100 & 0,85 & 6,3 & 8 & 249 & 3 & 70 & 100 & 34 & 500 & 199 & 320 & 199 & 19,0 \\
\hline & 11 & 131 & 100 & 0,85 & 6,3 & 8 & 249 & 3 & 70 & 100 & 34 & 500 & 199 & 320 & 199 & 19,0 \\
\hline & 14 & 104 & $250 / 1$ & 0,88 & 6,3 & 8 & 249 & 3 & 53 & 90 & 30 & 500 & 199 & 320 & 199 & 19,0 \\
\hline
\end{tabular}


rupture in $74 \%$ of the slabs with shear reinforcement which are in the data basis. This same behavior was also noticed by Ferreira [17] and is associated to the conservatism of the prescriptions for the definition of the external control perimeters ( $u_{\text {out }}$ e $u_{\text {out,eff). }}$ ). In his work, Ferreira [17] analyzed the possibility of changing the distance of detachment of $u_{\text {out }}$ in relation to the last reinforce-

\begin{tabular}{|c|c|c|c|c|c|c|c|c|c|c|c|}
\hline \multirow[b]{3}{*}{ Author } & \multicolumn{11}{|c|}{ Table 4 - Relationship between the experimental results and theoretical methods } \\
\hline & \multirow[b]{2}{*}{ Slab } & \multirow{2}{*}{$\begin{array}{l}V_{u} \\
(k N)\end{array}$} & \multirow{2}{*}{$\begin{array}{l}\text { Failure } \\
\text { surface }\end{array}$} & \multicolumn{2}{|c|}{ NBR -2007} & \multicolumn{2}{|c|}{ EC2 -2004 } & \multicolumn{2}{|c|}{$\mathrm{ACl}-2008$} & \multicolumn{2}{|r|}{ IFCC } \\
\hline & & & & $\mathrm{V} / \mathrm{V}_{\mathrm{NBR}}$ & $\begin{array}{c}\text { Failure } \\
\text { surface NBR }\end{array}$ & $\mathrm{V} / \mathrm{V}_{\mathrm{EC} 2}$ & $\begin{array}{c}\text { Failure } \\
\text { Surface EC2 }\end{array}$ & $\mathrm{V} / \mathrm{V}_{\mathrm{ACl}}$ & $\begin{array}{c}\text { Failure } \\
\text { Surface ACl }\end{array}$ & $\mathrm{V} / \mathrm{V}_{\text {IFCC }}$ & $\begin{array}{c}\text { Failure } \\
\text { Surface IFCC }\end{array}$ \\
\hline \multirow{3}{*}{$\begin{array}{l}\text { Regan } \\
(2009)\end{array}$} & 1 & 881 & in & 0,85 & out & 1,02 & out & 1,45 & out & 0,98 & out \\
\hline & 2 & 1.141 & fc/out & 0,94 & out & 1,13 & out & 1,71 & out & 1,17 & out \\
\hline & 3 & 1.038 & fc/in & 1,00 & out & 1,22 & out & 1,73 & out & 1,09 & out \\
\hline \multirow{12}{*}{$\begin{array}{l}\text { Birkle } \\
(2004)\end{array}$} & S1 & 435 & Ref. & 0,97 & Ref. & 1,11 & Ref. & 1,30 & Ref. & 1,13 & Ref. \\
\hline & $\mathrm{S} 2$ & 480 & in & 0,92 & out & 1,19 & out & 1,24 & out & 1,06 & in \\
\hline & S3 & 513 & in & 0,91 & out & 1,12 & out & 1,10 & out & 1,04 & in \\
\hline & S4 & 526 & out & 0,93 & out & 1,21 & out & 1,67 & out & 1,11 & out \\
\hline & S5 & 518 & out & 0,93 & out & 1,21 & out & 1,67 & out & 1,10 & out \\
\hline & S6 & 522 & out & 0,96 & out & 1,18 & out & 1,67 & out & 1,08 & out \\
\hline & S7 & 874 & Ref. & 0,92 & Ref. & 0,94 & Ref. & 1,12 & Ref. & 1,00 & Ref. \\
\hline & S8 & 1.070 & in & 0,84 & out & 0,98 & out & 1,29 & out & 0,91 & in \\
\hline & S9 & 1.025 & in & 0,98 & in & 1,06 & in & 1,28 & in & 1,10 & in \\
\hline & $\mathrm{S} 10$ & 1.335 & Ref. & 0,77 & Ref. & 0,78 & Ref. & 0,88 & Ref. & 0,84 & Ref. \\
\hline & $S 11$ & 1.626 & in & 0,86 & out & 1,00 & out & 1,24 & out & 0,93 & in \\
\hline & $\mathrm{S} 12$ & 1.687 & in & 0,82 & in & 0,90 & out & 1,03 & in & 1,00 & in \\
\hline \multirow{6}{*}{$\begin{array}{l}\text { Regan and } \\
\text { Samadian } \\
\text { (2001) }\end{array}$} & R3 & 850 & out & 0,85 & out & 1,04 & out & 1,44 & out & 1,05 & in \\
\hline & R4 & 950 & out & 0,90 & out & 1,10 & out & 1,39 & out & 1,12 & in \\
\hline & $\mathrm{A} 1$ & 1.000 & out & 0,88 & out & 1,08 & out & 1,50 & out & 1,20 & in \\
\hline & $\mathrm{A} 2$ & 950 & in & 0,93 & in & 1,03 & in & 1,42 & out & 1,10 & in \\
\hline & R5 & 1.440 & out & 0,95 & out & 1,09 & out & 1,08 & out & 1,07 & out \\
\hline & R6 & 1.280 & flex & 0,91 & out & 1,02 & out & 1,05 & out & 0,88 & in \\
\hline \multirow{11}{*}{$\begin{array}{c}\text { Gomes } \\
\text { and Regan } \\
\text { (1999) }\end{array}$} & 1 & 560 & Ref. & 0,88 & Ref. & 0,94 & Ref. & 1,16 & Ref. & 1,02 & Ref. \\
\hline & 2 & 693 & in & 1,14 & in & 1,26 & in & 1,64 & out & 1,19 & in \\
\hline & 3 & 773 & in/out & 1,10 & in & 1,21 & in & 1,64 & out & 1,22 & in \\
\hline & 4 & 853 & out & 1,03 & out & 1,27 & out & 1,98 & out & 1,36 & in \\
\hline & 5 & 853 & out & 1,01 & out & 1,24 & out & 1,77 & out & 1,21 & in \\
\hline & 6 & 1.040 & out & 1,01 & out & 1,23 & out & 2,07 & out & 1,44 & in \\
\hline & 7 & 1.120 & out & 1,13 & out & 1,38 & out & 2,02 & out & 1,43 & in \\
\hline & 8 & 1.200 & out & 1,20 & out & 1,48 & out & 1,90 & out & 1,53 & in \\
\hline & 9 & 1.227 & out & 0,92 & out & 1,09 & out & 1,70 & Max & 1,49 & in \\
\hline & 10 & 800 & in & 1,16 & in & 1,28 & in & 1,58 & in & 1,39 & in \\
\hline & 11 & 907 & in & 1,18 & in & 1,31 & in & 1,68 & out & 1,52 & in \\
\hline \multirow{6}{*}{$\begin{array}{l}\text { Codovil } \\
\text { (1995) }\end{array}$} & 7 & 320 & Ref. & 0,96 & Ref. & 1,08 & Ref. & 1,36 & Ref. & 1,05 & Ref. \\
\hline & 8 & 400 & in & 0,98 & in & 1,05 & in & 1,42 & in & 1,11 & in \\
\hline & 11 & 412 & in & 1,01 & in & 1,09 & in & 1,47 & in & 1,16 & in \\
\hline & 14 & 302 & in & 0,86 & in & 1,07 & out & 1,30 & out & 0,97 & in \\
\hline & & & Average & \multicolumn{2}{|r|}{0,97} & \multicolumn{2}{|r|}{1,13} & \multicolumn{2}{|c|}{1,48} & \multicolumn{2}{|r|}{1,16} \\
\hline & & & C.V & \multicolumn{2}{|r|}{0,11} & & 0,12 & \multicolumn{2}{|c|}{0,19} & \multicolumn{2}{|r|}{0,15} \\
\hline
\end{tabular}


ments layer of $1.5 d$ to $2 d$ and altering the criterion of the maximum transversal spacing between layers $\left(s_{t, \text { max }}\right)$ of $2 d$ to $4 d$. The author observed that such actions would substantially improve the predictions for $V_{\mathrm{R} \text {,out }}$, being more appropriate to the experimental evidences, but require adjusts also in the equation for $V_{R, c s}$, otherwise, this code would be thought of presenting a substantial number of results against safety. An alternative that may solve this problem would be to reduce the adjust coefficient of the Equation 10 from 0.18 to 0.16 as discussed by Sacramento et al. [21] and also by Oliveira [22].

The Critical Shear Crack Theory (CSCT) showed satisfactory results, having a 1.16 average value for the relation $V_{\mathrm{u}} / V_{\text {TFCC }}$ and a 0.15 coefficient of variation, with performance similar to EC2. In relation to the prediction of the rupture superficies, on the contrary of the other codes, CSCT presented a tendency to predict ruptures inside the area of the shear reinforcements, predicting this kind of rupture in $74 \%$ of the slabs of the data basis. Even though its predicts for the slabs rupture mode was inappropriate, being wrong about the position of the rupture superficies in $37 \%$ of the evaluated cases.

\section{Conclusions}

This paper discusses the use of shear reinforcements as one of the best manners to increase the punching resistance and the ductility of slab-column connections. It also presents in a succinct way the recommendations of the codes $\mathrm{ACl} 318$, NBR 6118 and Eurocode 2, besides the Critical Shear Crack Theory. It was made a small data basis with experimental results of tests in 36 slabs with double-headed studs or similar shear reinforcements, comparing these results with the theoretical ones obtained using the codes and CSCT.

Even considering that the data basis is limited due to the lack of tests with slabs with this kind of shear reinforcement, it is possible to observe that the recommendations presented by $\mathrm{ACl}$ may be conservative for the cases of slabs with shear reinforcements with good anchorage. The average of $V_{\mathrm{u}} V_{\mathrm{ACl}}$ was 1.48 and the coefficient of variation was 0.19 , substantially superior to the ones observed in the other theoretical methods. This elevated coefficient of variation was already expected once that $\mathrm{ACl}$ ignores important parameters in its equations, as the contribution of the flexion reinforcements, besides the reduction of the resistant tension with the increase o the useful height (size effect).

NBR 6118 showed that, despite presenting a 0.97 average results of $V_{\mathrm{u}} V_{\mathrm{NBR}}$ and a 0.11 coefficient of variation, the lowest among the evaluated methods, its equations present a strong tendency of results against safety. At the same moment the low coefficient of variation indicates that the parameters used in its equations present a good correlation with the tendency of the experimental results, the necessity of some adjustments becomes evident to avoid this tendency of insecure results, as it has already been highlighted by Ferreira [20] and Sacramento et al. [21].

Eurocode 2, by limiting $k$ and $r$ values, reduced the tendency of insecure results observed for NBR 6118, presenting the best results among the theoretical methods evaluated. For the small data basis presented, Eurocode 2 presented a 1.13 average of the relation $V_{\mathrm{u}} / V_{\mathrm{EC} 2}$ and a 0.12 coefficient of variation. Even though, it is evident that the authors could not experimentally observe justifications for the limitations imposed by Eurocode 2 for the size effect and for the flexural reinforcement ratio, considering technically more appropriate to perform adjusts in the coefficients of the formulations.

Brief comments on the Critical Shear Crack Theory must be made. This method showed sensible to the several variables common in the dimensioning of the flat slabs and presented results near the ones of EC2, although slightly more conservative for the data basis in question. In spite of its equations presenting, apparently, a strong empiric basis, the method is very well grounded and explains at a satisfactory mode the punching phenomenon. However, it must be emphasized that, as the method considers that the part of the slab external to the critical shear crack presents only rotations of rigid body and that the sliding of the superficies in the area of this crack does not occur, the method presents the tendency of estimating deformations and, consequently, superior stresses the most distant from the column the shear reinforcements are, when in reality the effect experimentally observed is the opposite. In practice, this may lead to inappropriate results for values of $s_{0}$ and $s_{r}$ near the minimum.

\section{Acknowledgements}

The authors would like to thank CNPq and CAPES for the financial support in all stages of this research.

\section{References}

[01] ACl Committee 318, Building Code Requirements for Structural Concrete (ACl 318-08) and Commentary, American Concrete Institute, Farmington Hills, Michigan, 2008.

[02] Eurocode 2, Design of Concrete Structures-Part 1-1: General Rules and Rules for Buildings, CEN, EN 1992-1-1, Brussels, Belgium, 2004, 225 pp.

[03] ASSOCIACAO BRASILEIRA DE NORMAS TECNICAS. NBR 6118 - Projeto de Estruturas de Concreto. Rio de Janeiro, 2007.

[04] RUIZ, M. F.; MUTTONI, A. Applications of Critical Shear Crack Theory to Punching of Reinforced Concrete Slabs with Transverse Reinforcement. ACl Structural Journal, July-August 2009. № 106-S46.

[05] fib Bulletins no. 65 e no. 66, Model Code 2010 - Final draft, Volume 1, 350p, Volume 2, 370p, 2012.

[06] GRAF, O..Versucheuber die Widerstandsfahigkeit von Eisenbetonplattenunterkonzentrierter Last naheeinem Auflager. Deutscher Ausschu $\beta$ fur Eisenbeton, Heft 73, Berlin, 1933, 16 pp.

[07] ELSTNER, R. C., e HOGNESTAD, E., Shearing Strength of Reinforced Concrete Slabs. Journal of the American Concrete Institute, Proceedings, V. 53, No. 1, Jul. 1956, pp. 29-58.

[08] ANDERSON, J. L., Punching of Concrete Slabs with Shear Reinforcement. Royal Institute of Technology, Bulletin, No. 212, KTH Stockholm, Sweden, 1963, 59p.

[09] BROMS, C.E., Elimination of Flat Plate Punching Failure Mode, ACI Structural Journal, V. 97, No. 1, Jan.-Feb. 2000, pp. 94-101. 
[10] REGAN, P. E., SAMADIAN, F., Shear Reinforcement against Punching in Reinforced Concrete Flat Slabs, The Structural Engineer, V. 79, No. 10, May 2001, pp. 24-31.

[11] OLIVEIRA, D. R., MELO, G. S., REGAN, P. E., Punching Strengths of Flat Plates with Vertical or Inclined Stirrups. ACI Structural Journal, V. 97, No. 3, May-June 2000, pp. 485-491.

[12] DILGER, W.H., and GHALI, A., Shear Reinforcement for Concrete Slabs, ASCE Journal of Structural Division, Proceedings, V. 107, No. ST12, Dec. 1981, pp. 2403- 2420.

[13] Comité Euro-International du Béton. CEB-FIP Model Code 1990. London, Thomas Telford, 1993.

[14] MUTTONI, A., and SCHWARTZ, J., Behaviour of Beams and Punching in Slabs without Shear Reinforcement, IABSE Colloquium, V. 62, Zurich, Switzerland, 1991, pp. 703-708.

[15] MUTTONI, A., Punching Shear Strength of Reinforced Concrete Slabs without Transverse Reinforcement, ACI Structural Journal, V. 105, No. 4, July-Aug. 2008, pp. 440-450.

[16] REGAN, P. E., Report on tests of reinforced concrete flat slabs with double-headed studs. Correspondência pessoal com o autor. 2009.

[17] BIRKLE, G., Punching of Flat Slabs: The Influence of Slab Thickness and Stud Layout. PhD Thesis. Department of Civil Engineering, University of Calgary, Calgary, Canada, 2004, 152 pp.

[18] GOMES, R. B. e REGAN, P. E., Punching Resistance of RC Flat Slabs with Shear Reinforcement. Journal of Structural Engineering, 1999, 684-692.

[19] CORDOVIL, F. A. B. Punção em Placas de Concreto Armado. Tese de Doutorado, Departamento de Engenharia de Estruturas e Fundações, Escola Politécnica da Universidade de São Paulo, 1995, 393p.

[20] FERREIRA, M. P. (2010). Punção em Lajes Lisas de Concreto Armado com Armaduras de Cisalhamento e Momentos Desbalanceados. Tese de Doutorado em Estruturas e Construção Civil, Publicação E.TD - 007 A/10 Departamento de Engenharia Civil e Ambiental, Universidade de Brasília, Brasília, DF, 275p.

[21] SACRAMENTO, P.V.P; FERREIRA, M.P; OLIVEIRA, D.R.C; MELO, G.S.S.A, Punching strength of reinforced concrete flat slabs without shear reinforcement. IBRACON Structures and Materials Journal. 2012. vol. $5, n^{\circ} 5$.

[22] OLIVEIRA, M. H. (2013). Punção Em Lajes Lisas Com Armadura de Cisalhamento Submetidas a Carregamento Excêntrico e Apoiadas Sobre Pilares Retangulares. Tese de Doutorado em Estruturas e Construção Civil, Publicação E.TD - 001 A/13 Departamento de Engenharia Civil e Ambiental, Universidade de Brasília, Brasília, DF, 223p. 